\title{
SALMONELLOSIS AND DETECTION RATE OF SALMONELLA SPP. IN FOODSTUFFS
}

\author{
Ruda M. Ye., Kozutska T. G., Yaremenko R. M., Balanchuk L. V. \\ State Scientific and Research Institute of Laboratory Diagnostics and Veterinary \\ and Sanitary Expertise, Kyiv, Ukraine, e-mail: rudaya2020@gmail.com
}

\begin{abstract}
Summary. Today, salmonellosis remains one of the leaders in zoonoses and the cause of toxic infections in humans, which are common throughout the world. The epidemiological feature of salmonellosis is suddenness and mass character. Salmonella is very stable in the environment, and can multiply intensively at $20-37^{\circ} \mathrm{C}$ in various foods: meat and dairy products, sausages, especially blood and liver, jellies, pates, cream confectionery, salads and other dishes. The organization and conduct of laboratory tests for the diagnosis and prevention of salmonellosis is an important component of the epidemiological surveillance system. The aim of the study was to analyze the detection rate of bacteria of the genus Salmonella in food products on the territory of Ukraine in 2019 and to establish the serovars of Salmonella, dangerous to human health. The study and analysis of statistical data was carried out based on the results of research and reports from the regional laboratories of the State Food and Consumer Service of 24 regions of Ukraine, as well as own research conducted in the State Scientific and Research Institute of Laboratory Diagnostics and Veterinary and Sanitary Expertise. According to the results of the research, it was established that 72 isolates of Salmonella spp. were isolated out of 184,951 food samples studied in 2019. Compared to 2018, the number of isolated salmonella from 189,517 samples was 121 isolates, of which dangerous strains of $S$. Enteritidis (group D) were detected in 25 cases, which is $20.6 \%$, and Salmonella spp. $-32.2 \%$ of all isolated salmonella. These variants of salmonella were isolated from meat of various species of animals, poultry co-products, meat semi-finished products, minced meat and mechanically deboned meat, sauce, eggs and feed. In 2017, only 32 isolates of Salmonella were isolated from 142,977 tested samples, mainly Salmonella spp. The products from which this pathogen was isolated differed slightly from the following years, namely: meat, co-products, meat semi-finished products, animal oil, salted fish, fish semi-finished products and cookies. That is, the largest number of isolated salmonella is observed in 2018, although the number of samples in 2019 was slightly lower than in 2018. Thus, the obtained data indicate that it is necessary to follow strictly the sanitary and hygienic rules during the preparation, processing and consumption of food
\end{abstract}

Keywords: bacteriological studies, Ukraine, serovars

Introduction. Salmonellosis is an infectious disease of animals, birds and humans, which is characterized by acute course, fever, diarrhea and lesions of the small and large intestine, and in chronic course - pneumonia.

The source of the pathogen is sick and diseased animals-carriers and their feces, and the route of transmitting the pathogen is the fecal-oral route. Animals can secrete the pathogen for months, sick humans - from 3 days to 3 weeks.

For humans and pets, the source of infection can be meat and meat products from animals-carriers, fish and seafood, eggs and egg products, milk and dairy products, vegetables and fruit (Afshari, 2018; Crump et al., 2015; Eng et al., 2015).

In $96-98 \%$ of cases, infections are related to the consumption of salmonella-contaminated food. In food, especially in semi-finished products, salmonella are not only stored, but they also multiply rapidly, without changing the taste of dishes (Percival and Williams, 2014; Antunes et al., 2016).

In the last 20 years, the largest outbreak of salmonellosis has been recorded in the United States, which was caused by infected ice cream, which in turn was made from contaminated eggs. The outbreak affected 224,000 people (Seladi-Schulman and Brazier, 2020; Beuchat and Mann, 2015).
The most common form of salmonellosis is gastrointestinal. It begins with intoxication, and is characterized by a temperature of up to $39^{\circ} \mathrm{C}$, headache, chills, weakness, aches and dizziness. At the same time, the symptoms of gastrointestinal dysfunction increasestomach pain, vomiting, diarrhea, etc.

Separately, we can distinguish salmonellosis in subclinical form, as well as carriage of bacteria with a chronic state that does not manifest itself clinically and is detected exclusively by laboratory methods (Allaoui and Filali, 2016; Galatiuk et al., 2016).

Salmonella are highly resistant to drying, high temperatures and other adverse environmental conditions, and can be stored at its facilities for 160 days; in manure - 420 days, in salted and smoked meat 2.5-3 months; in cheese and butter - up to 6 months. They withstand freezing for $4-5$ months, and are stored in sunlight for 150 days. When heated to $70-75^{\circ} \mathrm{C}$ they are inactivated during $15-30 \mathrm{~min}$ and some can withstand temperatures up to $85^{\circ} \mathrm{C}$ for $45 \mathrm{~min}$ (Crump et al., 2015; Eng et al., 2015). Today, the problem of antibiotic resistance of microorganisms released from biological material and food is relevant (Hadzevych et al., 2019).

The aim of the study was to analyze the frequency of detection Salmonella in food products in 2019 in Ukraine and to establish dangerous to human health serovars. 
Materials and methods. In order to establish the spread of bacteria of the genus Salmonella in food products the results of research and reports from the regional laboratories of the State Food and Consumer Service of 24 regions of Ukraine, as well as the results of studies of the Laboratory for Microbiological Researches of Foodstuffs the State Scientific and Research Institute of Laboratory Diagnostics and Veterinary and Sanitary Expertise (Kyiv) were analyzed. The following foodstuffs were studied: pork and beef, minced meat of poultry and other animals, meat and fish semi-finished products, eggs, cheese, fresh chilled fish, seafood. A total of 184,951 food samples were studied in 2019. Bacteriological studies were performed by conventional methods following ISO 65791:2017 'Microbiology of the Food Chain - Horizontal Method for the Detection, Enumeration and Serotyping of Salmonella - Part 1: Detection of Salmonella spp.' (ISO, 2017) respectively to each test product.

Prepared food samples were added to non-selective enrichment media with subsequent enrichment on selective media and subcultured on solid differential diagnostic media. After incubation, the enriched material was transplanted into selective enrichment media (Mueller-Kaufmann and Rappaport-Vasiliadis), and then into differential diagnostic media, respectively.

Identification of isolated cultures was performed on the basis of their cultural-morphological and biochemical properties. Subsequently, serotyping of salmonella isolates was performed to detect $\mathrm{O}-$ and $\mathrm{H}$-antigens. Determination of antigenic belonging was performed in the agglutination test on glass with polyvalent serum $\mathrm{ABCDE}$ and determination of the O-group of salmonella using monovalent sera.

Results and discussion. Studies have identified 72 positive cases of Salmonella spp. These data were obtained from 12 regions of Ukraine: Volyn, Dnipropetrovsk, Donetsk, Zhytomyr, Zaporizhzhia, Mykolaiv, Odesa, Poltava, Rivne, Khmelnytsky, and Cherkasy. The percentage of indication of the pathogen in food in different areas is presented in Fig. 1.

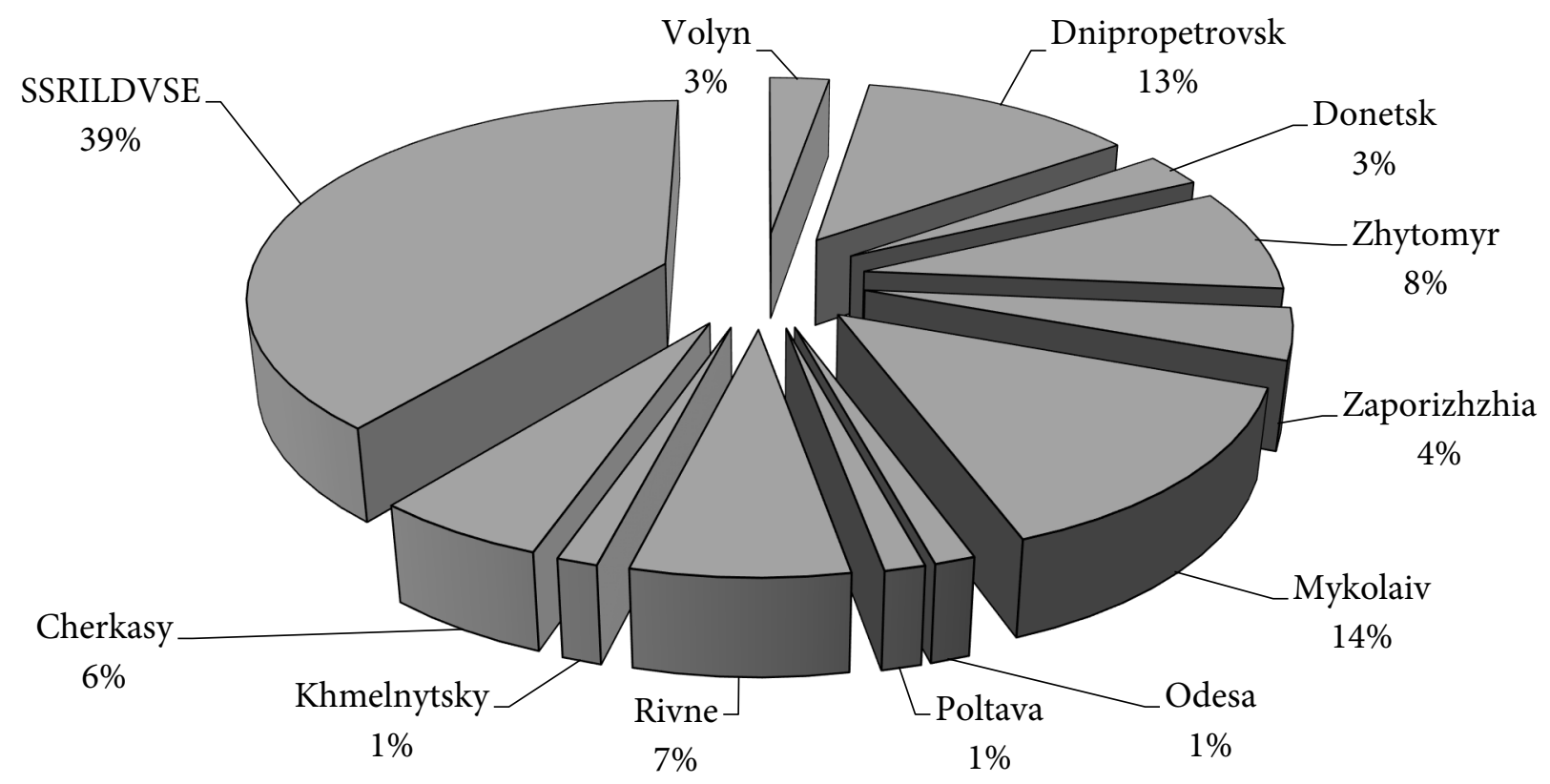

Figure 1. Percentage of cases of Salmonella detection in the regions of Ukraine

The highest number of salmonella was observed in Zhytomyr Region - 6(8.3\%), Mykolaiv Region 10 (13.8\%), Dnipropetrovsk Region - $9(12.5 \%)$, and in samples received for research at SSRILDVSE in Kyiv $28(38.8 \%)$ isolates.

The highest amount of salmonella was found in meat products, which was $40.3 \%$ (Fig. 2). In semi-finished products, this index reached $28 \%$, finished products contained $13.9 \%$ and $4.2 \%$ of the pathogen accounted for eggs and egg products, respectively.

Thus, in the meat of different species of animals 4 positive samples (of the total number of positives), poultry meat - $11(15.2 \%)$, in minced meat and mechanically deboning meat $-9(12.5 \%)$. Quite a large number of positive results was obtained in the study of meat semi-finished products, which was 18 samples (25\%). In the finished meat products there was a significant amount of Salmonella, which was 4 positive samples (5.5\%). In 2019, in the study of feed for microbiological indicators, 9 (12.5\%) samples with Salmonella were isolated.

By serotyping (Table 1), it was determined that Salmonella group D and Salmonella group C composed 19 and 16 isolates, respectively, of all tested products. $S$. Typhimurium and S. Haifa composed two cases, and Salmonella spp. - nine. This indicates a high probability of infection of pets with salmonella or their subsequent bacteria carriage. 


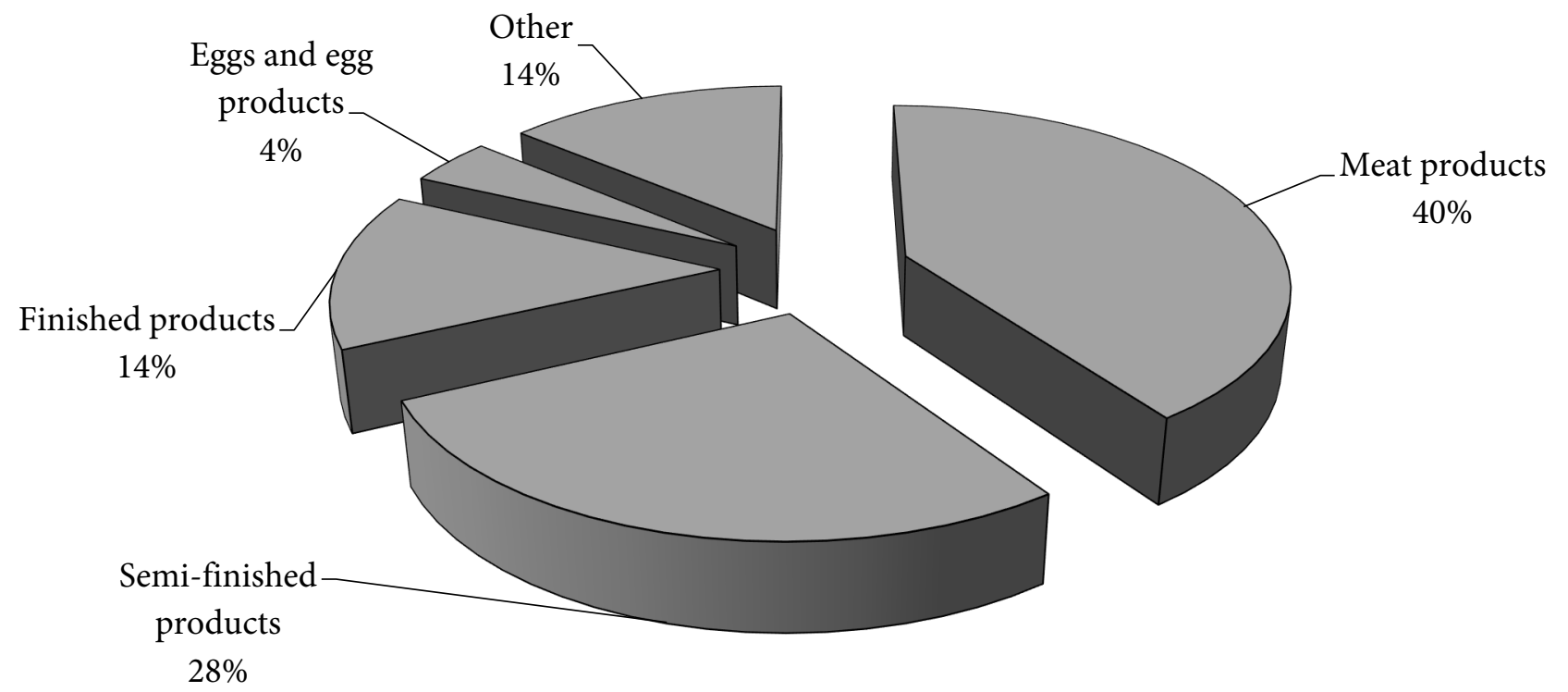

Figure 2. Percentage of cases of Salmonella detection in different food products

Table 1 - Serological structure of Salmonella isolated from different products

\begin{tabular}{|c|c|c|c|c|c|c|c|c|c|c|c|}
\hline \multirow{2}{*}{\multicolumn{2}{|c|}{ Type of product or raw material }} & \multicolumn{10}{|c|}{ Salmonella serovars/serogrups } \\
\hline & & \multirow{2}{*}{\begin{tabular}{|c|}
$\begin{array}{c}\text { Group } \\
\text { D }\end{array}$ \\
5
\end{tabular}} & \multirow{2}{*}{\begin{tabular}{|c|}
$\begin{array}{c}\text { Group } \\
\text { E }\end{array}$ \\
- \\
\end{tabular}} & \multirow{2}{*}{$\begin{array}{c}\text { Group } \\
\text { C } \\
3\end{array}$} & \multirow{2}{*}{\begin{tabular}{c|}
$\begin{array}{c}\text { Group } \\
\text { B }\end{array}$ \\
2 \\
\end{tabular}} & \multirow{2}{*}{$\begin{array}{c}S . \\
\text { spp. } \\
- \\
\end{array}$} & \multirow{2}{*}{$\begin{array}{c}\begin{array}{c}\text { Enteri- } \\
\text { tidis }\end{array} \\
3 \\
\end{array}$} & \multirow{2}{*}{\begin{tabular}{|c|}
$\begin{array}{c}\text { Typhi- } \\
\text { murium }\end{array}$ \\
- \\
\end{tabular}} & \multirow{2}{*}{$\begin{array}{c}\begin{array}{c}\text { Galli- } \\
\text { narum }\end{array} \\
- \\
\end{array}$} & \multirow{2}{*}{\begin{tabular}{|c|} 
Haifa \\
-
\end{tabular}} & \multirow{2}{*}{\begin{tabular}{|c} 
Total \\
13
\end{tabular}} \\
\hline \multirow{4}{*}{$\begin{array}{l}\text { Meat } \\
\text { products }\end{array}$} & poultry meat & & & & & & & & & & \\
\hline & $\begin{array}{l}\text { meat from other animal } \\
\text { species }\end{array}$ & 1 & - & - & - & - & - & - & - & - & 1 \\
\hline & $\begin{array}{l}\text { minced meat and mecha- } \\
\text { nically deboning meat }\end{array}$ & 4 & 1 & - & - & 4 & - & - & - & - & 9 \\
\hline & by-products & - & - & 4 & - & - & 1 & - & - & - & 5 \\
\hline \multirow{3}{*}{$\begin{array}{l}\text { Semi- } \\
\text { finished } \\
\text { products }\end{array}$} & from meat & 3 & - & 7 & 4 & - & 2 & - & 1 & - & 17 \\
\hline & from fish & - & - & - & - & - & 1 & - & - & - & 1 \\
\hline & without meat & - & - & - & - & - & 1 & - & - & - & 1 \\
\hline \multirow{7}{*}{$\begin{array}{l}\text { Finished } \\
\text { products }\end{array}$} & meat & 3 & - & - & - & - & 1 & - & - & - & 4 \\
\hline & fish & 1 & - & - & - & - & - & - & - & - & 1 \\
\hline & cheese & - & - & - & - & - & 1 & - & - & - & 1 \\
\hline & soups, porridges and other & - & - & - & - & - & 1 & - & - & - & 1 \\
\hline & confectionery & - & - & - & - & - & 1 & - & - & - & 1 \\
\hline & caviar, mollusks & 1 & - & - & - & - & - & - & - & - & 1 \\
\hline & sauces & - & - & - & - & - & - & 1 & - & - & 1 \\
\hline \multicolumn{2}{|c|}{ Eggs and egg products } & 1 & - & 1 & - & - & 1 & 1 & - & - & 4 \\
\hline \multicolumn{2}{|c|}{ Casein, gelatin } & - & - & 1 & - & - & - & - & - & - & 2 \\
\hline \multicolumn{2}{|c|}{ Animal feed } & - & - & - & - & 5 & 2 & - & - & 2 & 9 \\
\hline \multicolumn{2}{|c|}{ Total } & 19 & 1 & 16 & 6 & 9 & 15 & 2 & 1 & 2 & 72 \\
\hline
\end{tabular}

Most salmonella are pathogenic for both humans and animals, but the most dangerous in epidemiological terms for humans were isolated $S$. Enteritidis in 15 cases (poultry meat, by-products from farm animals and poultry, semifinished fish, eggs, dairy products) and $S$. Typhimurium in one case from the sauce and in one case - from eggs. It should be noted that $S$. Enteritidis has become widespread in the last 20 years. Representatives of this serovar cause outbreaks of salmonellosis at low doses of contamination of the product, and diseases are usually characterized by more expressed clinical manifestations.

Summarizing the results, we can say that the largest number of salmonella cases were registered in food products that require heat treatment (meat, minced meat, semi-finished products), and a slightly lower percentage - in ready-to-eat food products. 
Therefore, due to the fact that salmonellosis has severe courses and consequences, and the pathogen is very resistant and can adapt to the macroorganism for symbiosis, preventive measures and control measures must be strict and effective. In veterinary medicine, the prevention of salmonellosis should be aimed at increasing the organism resistance of the broodstock and newborns. Feeding with contaminated with salmonella feed is not allowed. Feed for animals must be tested bacteriologically. Timely deratization of the premises is required.

It is necessary to adhere more strictly to sanitary and hygienic rules during cooking, to use only sufficiently heat-treated meat, milk, eggs, or products from them. Strictly separate storage places for raw and finished products. It is forbidden to buy dairy and meat products, eggs at spontaneous markets, and it is necessary to pay attention to the temperature of storage of these products in shopping facilities. Do not consume expired products. It is necessary to maintain personal hygiene to prevent the getting the pathogen into the body: to wash hands with soap after the toilet, before eating and cooking. Be sure to wash vegetables and fruit thoroughly under running water. Timely deratization and disinsection of food storage facilities are required.

It should be noted that salmonella of any serovars can cause a wide variety of clinical forms of the disease - from severe generalized forms to asymptomatic carriage.
Conclusions. 1. During 2019, 184,951 food samples were studied, from which 72 isolates of Salmonella in 12 regions of Ukraine were identified. The largest number of Salmonella cases was registered in Zhytomyr Region 6 (8.3\%), Mykolaiv Region - 10 (13.8\%), Dnipropetrovsk Region $-9(12.5 \%)$, and in samples received for research at SSRILDVSE in Kyiv - 28 (38.8\%).

2. Products contaminated with salmonella, that require heat treatment accounted for $73 \%$ of the total amount of salmonella isolated, $26 \%$ - are ready to eat products.

3. The most dangerous Salmonella serovars group D (S. Enteritidis) were isolated from poultry meat, byproducts from farm animals and poultry, semi-finished fish, eggs, and dairy products; group B (S. Typhimurium) from sauce and eggs.

4. Compared to 2018, the number of isolated salmonella from 189,517 samples was 121 isolates, of which dangerous strains of $S$. Enteritidis (group D) were detected in 25 cases, which is $20.6 \%$, and S. spp. $-32.2 \%$ of all isolated salmonella. In 2017, only 32 isolates of Salmonella were identified from 142,977 tested samples, mainly Salmonella spp.

Prospects for further research. Salmonellosis in animals and humans is an acute medical and veterinary problem, which justifies its permanent monitoring.

\section{References}

Afshari, A., Baratpour, A., Khanzade, S. and Jamshidi, A. (2018) 'Salmonella Enteritidis and Salmonella Typhimorium identification in poultry carcasses', Iranian Journal of Microbiology, 10(1), pp. 45-50. PMID: 29922418.

Allaoui, A. E. and Filali, F. R. (2016) 'Occurrence and antimicrobial-resistant Salmonella serovars isolated from turkey carcasses and broiler turkey farms in Meknès-Morocco, Fermentation Technology, 5(3), p. 132. doi: 10.4172/2167-7972. 1000132.

Antunes, P., Mourão, J., Campos, J. and Peixe, L. (2016) 'Salmonellosis: The role of poultry meat', Clinical Microbiology and Infection, 22(2), pp. 110-121. doi: 10.1016/j.cmi.2015.12. 004 .

Beuchat, L. R. and Mann, D. A. (2015) 'Survival of Salmonella in cookie and cracker sandwiches containing inoculated, low-water activity fillings', Journal of Food Protection, 78(10), pp. 1828-1834. doi: 10.4315/0362-028X.JFP-15-142.

Crump, J. A., Sjölund-Karlsson, M., Gordon, M. A. and Parry, C. M. (2015) 'Epidemiology, clinical presentation, laboratory diagnosis, antimicrobial resistance, and antimicrobial management of invasive Salmonella infections', Clinical Microbiology Reviews, 28(4), pp. 901-937. doi: 10.1128/CMR. 00002-15.

Eng, S.-K., Pusparajah, P., Ab Mutalib, N.-S., Ser, H.-L., Chan, K.-G. and Lee, L.-H. (2015) 'Salmonella: A review on pathogenesis, epidemiology and antibiotic resistance', Frontiers in Life Science, 8(3), pp. 284-293. doi: 10.1080/21553769.2015. 1051243.
Galatiuk, O. Ye., Peredera, O. O, Lavrinenko, I. V and Zhernosik, I. A. (2016) Infectious Diseases of Cats [Infektsiini khvoroby kotiv]. Zhytomyr: Polissia. Available at: http://ir.znau. edu.ua/handle/123456789/5644. [in Ukrainian].

Hadzevych, O. V., Paliy, A. P., Kinash, O. V., Petrov, R. V. and Paliy, A. P. (2019) 'Antibiotic resistance of microorganisms isolated from milk' [Antybiotykorezystentnist mikroorhanizmiv, izolovanykh z moloka], World of Medicine and Biology, 3, pp. 245-250. doi: 10.26724/2079-8334-2019-3-69-245-250. [in Ukrainian].

ISO (International Organization for Standardization). (2017) ISO 6579-1:2017: Microbiology of the Food ChainHorizontal Method for the Detection, Enumeration and Serotyping of Salmonella - Part 1: Detection of Salmonella spp. Geneva: ISO. Available at: https://www.iso.org/standard/56712. html.

Percival, S. L. and Williams, D. W. (2014) 'Chapter Ten Salmonella', in Percival, S. L., Yates, M. V, Williams, D. W., Chalmers, R. M. and Gray, N.F. (eds.) Microbiology of Waterborne Diseases: Microbiological Aspects and Risks. $2^{\text {nd }}$ ed. London: Academic Press, pp. 209-222. doi: 10.1016/B978-0-12415846-7.00010-X.

Seladi-Schulman, J. and Brazier, Y. (2020) 'All you need to know about salmonella', Medical News Today, [updated on March 12, 2020]. Available at: https://www.medicalnewstoday. com/articles/160942. 